TURIZAM

Volume 24, Issue 3

$113-124(2020)$

ORIGINAL

SCIENTIFIC PAPER

\title{
The Effect of Servicescape in Hotels on Customer Satisfaction: Evidence From Resort Hotels
}

\author{
Savaş Artuğer ${ }^{\mathrm{A}}$ \\ Received: March 2020 | Accepted: July 2020 \\ DOI: 10.5937/turizam24-25540
}

\begin{abstract}
The purpose of this study was to determine the impact of servicescapes in hotels on customer satisfaction. The sample of the study consists of foreign tourists staying in five-star resort hotels operating in Marmaris district of Muğla province between June 1-August 30, 2019. Data were collected from 225 hotel customers. Mean, standard deviation, confirmatory factor analysis, reliability analysis and regression analysis were used in analyzing the obtained data.

The study revealed that servicescape in hotels has an impact on customer satisfaction. It was found that ambient conditions, decor, signs and symbols had a significant effect on customer satisfaction. According to the results of the study, signs and symbols are the most important factors affecting customer satisfaction. However, it was discovered that the spatial layout did not affect customer satisfaction.
\end{abstract}

Keywords: servicescape; customer satisfaction; resort hotels

\section{Introduction}

Servicescape refers to the comprehensive physical environment perceived by customers and consists of elements such as facilities, furniture, signs, temperature, noise, cleanliness. The servicescape in a hotel is influential on people's buying behavior and market segmentation of hotels (Hee Lee, Lee, 2015). However, due to the simultaneous consumption and production in hotels, which are due to the characteristics of the service industry, customers have little knowledge of the services in a hotel. Therefore, customers have to deal with high levels of uncertainty. This is a risk factor for customers (Reimer, Kuehn, 2005). At this point, servicescape components can play an important role in the customer's knowledge of the hotel business and make a relevant evaluation of it.

Hotel customers often spend most of their time in the hotel for various reasons. This situation is observed more often especially in hotels that implement the all-inclusive system. During their stay at the hotel, hotel customers, consciously or unconsciously, perceive the atmos-

A Muğla Sıtkı Koçman University, Faculty of Tourism, Muğla, Turkey; Corresponding author: artugersavas@yahoo.com 
phere of service, which significantly affects their future intentions (Adyozi, Klutse, 2015). In addition, customers who have not had any previous experience in the facility are affected by the servicescape and because they are in the relevant atmosphere for the first time, the business-customer connection can be formed more solidly. Furthermore, since the customer is having a new experience, he/she may have a more emotional perception of value (Dedeoğlu et al., 2018).

Customer satisfaction is one of the most important marketing priorities for businesses. Customer satisfaction has a significant impact on repurchase, positive word-of-mouth, and customer loyalty (Ryu, Han, 2010). Of course, there are many factors that affect customer satisfaction in hotels. These elements can be listed as bed comfort, cleanliness of bathrooms, room size, location and accessibility, food and beverage quality, personnel performance, service quality, perceived value (Choi, Chu, 2001; Hu et al., 2009). However, given the expectations of today's consumers, focusing only on these elements may be insufficient to ensure customer satisfaction in hotel businesses. In this context, this study aimed to determine the impact of servicescapes in hotels on customer satisfaction.

The flow of the article is as follows. Firstly, servicescape and customer satisfaction are explained. Then, a literature review and hypotheses about the effect of servicescape on customer satisfaction are given. In the next section, research method findings and results are given.

\section{Servicescape}

Servicescape is defined as a combination of various dimensions that affect a customer's overall perceptions of the service (Miles et al., 2012). Although servicescape is the most commonly used term to emphasize the impact of abstract and concrete elements on consumers, other terms have also been used to describe the same concept (Hooper et al., 2013). Baker (1987) has conceptualized servicescape as the "physical environment", Kotler (1973) "atmosphere", Arnold et al (1996) "economic environment", Turley and Milliam (2000) "marketing environment", Mathwich et al (2001) "interactive theatre", Roy, Tai ( 2003) "store environment", Weinrach (2000) "psychological environment" and Cronin (2003) as a "service environment" (Juhari et al., 2012).

Bitner (1992) refers to servicescape as the physical environment or the surroundings of an environment in an enterprise where service is delivered. According to Bitner, servicescape consists of the overall or holistic structuring of the environmental dimension rather than a single component. Servicescape generates specific emotional responses in customers and helps customers categorize the services (Miles et al., 2012). In addition, servicescape affects people's views about a place, other people and/or products (Bitner, 1992). This is because servicescape includes physical dimensions that affect the five senses of consumers (Joanne Chan et al., 2019). However, the dimensions of servicescape can play an important role in planning and designing services (Miles et al., 2012).

Bitner (1992) divided servicescape into three dimensions. These dimensions are ambient conditions, spatial layout, signs, symbols and artifacts. Ambient conditions refer to elements such as temperature, lighting, noise, music and odors. Spatial layout refers to the order of furnishing and equipment where the service is delivered (Siu et al., 2012). Signs, symbols and artifacts express open or closed elements with which people interact in an environment (Liu, Jang, 2009). 
The authors who use the concept of servicescape in different ways have revealed different dimensions. Turley and Milliman (200o) divided the elements of the atmosphere into five groups. These elements comprise of external variables, general internal variables, layout variables, purchase and decoration variables and human variables. Rosenbaum and Massiah (2011) explained the atmosphere in four dimensions. These dimensions are the physical dimension: environmental conditions, social dimension: employees, customers, social concentration and feelings displayed by other people, social symbolic dimension: ethnic signs /symbols, ethnic objects/works of art, natural dimension: charm and harmony. Kotler (1973) divided the atmosphere into four dimensions: visual: color, brightness, size, form, aural: sound, pitch, olfactory: odors, freshness, tactile: softness, temperature.

\section{Customer Satisfaction}

Customer satisfaction has become a popular research topic since it is an important issue for establishing long-term relationships with customers (Cheng et al., 2019). There are different definitions of customer satisfaction in the literature by different authors. According to Del Bosque et al. (2006), customer satisfaction refers to the cognitive and emotional evaluations of consumers' after the use or consumption of a product. Customer satisfaction is an evaluation based on a comparison between customers' experiences and expectations ( $\mathrm{Xu}, \mathrm{Li}, 2016)$. Dominici and Guzzo (2010:2) suggested another definition of customer satisfaction as "business philosophy which tends to the creation of value for customers, anticipating and managing their expectations, and demonstrating ability and responsibility to satisfy their needs".

Although customer satisfaction is one of the main objectives of managers in hotel businesses (González-Mansilla et al., 2019), it is one of the biggest challenges that managers face (YenLun $\mathrm{Su}, 2004)$. At this point, customer satisfaction measurements can help hotel managers understand the actual requirements and needs of customers (Radojevic et al., 2015). There are many factors that affect customer satisfaction in hotel establishments. According to Qu et al. (200o) these factors refer to staff performance, quality of rooms, value for money paid, variety of services and security. According to Gu and Ryan (2008) it means bed comfort, cleanliness of bathrooms, room size, location and accessibility, food and beverage quality and staff performance. Other factors affecting customer satisfaction can be listed as service quality, perceived value and characteristics of the rooms (Choi, Chu, 2001; Hu et al., 2009).

\section{Effect of Servicescape on Customer Satisfaction}

When the studies investigating the effect of service environment on customer satisfaction in tourism enterprises are examined, it is generally seen that the studies are carried out in hotels (Lin, 2009; Faizan, Muslim, 2014; Adzoyi, Klutse, 2015; Lap-Kwong, 2017) and restaurants (Han, Ryu, 2009; Ryu, Han, 2010; Ryu, 2010; Voon, 2011; Heung, Gu, 2012).

In their study regarding 1-3 star hotels in Ghana, Adyozi and Klutse (2015) concluded that servicescape in hotels has an impact on customer satisfaction. The authors concluded that especially tools-equipment, odors and lighting had more impact on customer satisfaction in their study. Faizan and Muslim (2014) determined that physical environments have an impact on customer satisfaction in their study at resort hotels in Nanjing, Hangzhou and Shanghai. In their study carried out in the hotel buffet restaurant, Lap-Kwong (2017) revealed that clean- 
liness is the most important factor affecting customer satisfaction. Lin (2009) concluded that music and colors used in hotel bars affect customer satisfaction.

In their studies on restaurants, Han and Ryu (2009) found that decor and artifacts in restaurants have a positive effect on customer satisfaction. Ryu and Han (2010) discovered that atmospheric elements in fast food restaurants have an impact on customer satisfaction. Similarly, Voon (2011) carried out a survey of young customers eating at fast-food restaurants in Malaysia. As a result of this study, it was concluded that atmospheric factors have an effect on customer satisfaction. Heung and $\mathrm{Gu}$ (2012) found that atmospheric elements such as seating arrangement in the restaurants, employees, ambience, plant aesthetics and the appearance of the windows had an impact on customer satisfaction in luxury restaurants in Hong Kong. Ryu (2010) conducted a survey of luxury restaurants in the Northwest and Southeast of the United States, revealing that facility aesthetics, lighting, ambience, seating and service personnel have an impact on customer satisfaction. Based on the literature review, the hypotheses of this study are as follows:

$\mathrm{H}_{1}$ : Hotel servicescapes have a positive influence on customer satisfaction.

$\mathrm{H}_{1 \mathrm{a}}$ : Ambient conditions have a positive influence on customer satisfaction.

$\mathrm{H}_{1 \mathrm{~b}}$ : Layout has a positive influence on customer satisfaction.

$\mathrm{H}_{1 \mathrm{c}}$ : Decor has a positive influence on customer satisfaction.

$\mathrm{H}_{1 \mathrm{~d}}$ : Signs and symbols have a positive influence on customer satisfaction.

\section{Methodology}

\section{Research instrument}

The survey technique was used as a data collection tool in this study. The survey form consisted of three sections. The first part consisted of the demographic characteristics of the participants (gender, age, education level, nationality) and the frequency of visiting the hotel. The second part consisted of a scale measuring the hotel's servicescape which was comprised of 13 items and 4 basic dimensions (ambient conditions, spatial layout, decor, signs and symbols). In the third part, customer satisfaction was measured with 4 statements.

The questions measuring the servicescape of the hotels were prepared from the study conducted by Dedeoğlu et al. (2015). Questions regarding customer satisfaction were taken from the study conducted by Kwortnik and Han (2011). In both scales, the participants' levels of agreement were graded according to the 5 -point Likert scale as Strongly disagree = 1 "," Disagree $=2$ ", " Neutral = 3 ", " Agree = 4 " and" Strongly agree $=5$. The survey was conducted between June and August 2019.

\section{Sampling and Data Collection}

The sample of this study, which aims to determine the effect of the elements of servicescape in hotels on customer satisfaction, consists of foreign tourists staying in five-star hotels operating in the Marmaris district of Muğla province between June 1-August 30, 2019. Turkey's Muğla province is the third city that attracts the most tourists. According to 2018 data, 2,805,115 tourists came to Muğla (Muğla Provincial Directorate of Culture and Tourism, 2019). Marmaris is a port bay connected to Muğla Province at the intersection point of the Aegean and Mediterranean in southwestern Turkey. 663,372 tourists came to Marmaris according to data for 
2018 (Republic of Turkey Ministry of Culture and Tourism, 2019). There are 17 five-star hotels in Marmaris. Initially, interviews were made with these 17 hotels. Five of these hotels declined from being included in the survey. Therefore, the survey was carried out with the remaining 12 hotels. These hotels are resort hotels that implement the all-inclusive system. Five of the twelve hotels that agreed to take the survey accepted the questionnaires on the condition that they were applied by the hotel staff. For this reason, the questionnaire forms of the research were delivered to the front office managers of the relevant hotels. The surveys conducted in seven hotels outside these hotels were conducted face-to-face with the tourists who agreed to participate in the survey in the lobby of the relevant hotels by the person carrying out the research. The surveys were prepared in English.

Since it was not possible to determine the sample list, the convenience sampling method, which is one of the non-random sampling methods, was used in this study. Confirmatory factor analysis is appropriate when the sample size is 200 or over (Myers et al., 2011). In this study, a questionnaire was collected from 230 people. Five of the surveys were discarded because they were incomplete and inaccurate and 225 questionnaires were taken into consideration.

\section{Data Analysis}

Initially, the frequency and percentage distributions of the participants staying in five-star resort hotels in Marmaris have been determined in terms of demographic characteristics (gender, age, education level, nationality). The arithmetic mean and standard deviation values have been calculated in order to describe the opinions of foreign tourists regarding hotel servicescape and satisfaction.

Confirmatory factor analysis was carried out to ensure the construct validity of the hotel servicescape scale. A check was carried out to determine whether there were any missing data and whether outliers and data showed normal distribution before the confirmatory factor analysis (Woo et al., 2015; Evangelista, Dioko, 2010). No missing data were encountered. No outliers were detected either. The normality of the distribution of the obtained data was determined by the skewness and kurtosis values of each expression. According to Shiel and Cartwright (2015:28) the skewness and kurtosis values for each expression must be determined as between -1 and +1 for normal distribution. As a result of the analysis, the skewness and kurtosis values of each expression were found to be between -1 and +1 . Furthermore, the reliability of the scale was determined by Cronbach's alpha coefficient. Multiple linear regression analysis was carried out in order to determine the effect of hotel servicescape (ambient conditions, spatial layout, decor, signs and symbols) on customer satisfaction.

\section{Research Findings}

According to the findings in Table 1,39.5\% of the participants were male and 57.4\% were female. More than half (60.9\%) of the participants were between the ages of 21-40. The majority (81.4\%) of the participants consisted of people with high school, associate degree and undergraduate education. The participants were mainly British, Russian and Dutch tourists. While $22.7 \%$ of the participants came to the hotel for the first time, $38.7 \%$ came for the second time and $23.1 \%$ came for the third time. 
Table 1. Demographic profile of the respondents

\begin{tabular}{|c|c|c|}
\hline Characteristics & Frequency & Percentage (\%) \\
\hline \multicolumn{3}{|l|}{ Gender (valid $n=220$ ) } \\
\hline Male & 89 & 39.6 \\
\hline Female & 131 & 58.2 \\
\hline \multicolumn{3}{|l|}{ Age (valid n=225) } \\
\hline 20 and under & 29 & 12.9 \\
\hline $21-30$ & 78 & 34.7 \\
\hline $31-40$ & 50 & 22.2 \\
\hline $41-50$ & 30 & 13.3 \\
\hline $51-60$ & 22 & 9.8 \\
\hline 61 and over & 16 & 7.1 \\
\hline \multicolumn{3}{|c|}{ Education level (valid $n=218$ ) } \\
\hline Primary education & 28 & 12.4 \\
\hline High school & 94 & 41.8 \\
\hline Associate degree & 38 & 16.9 \\
\hline Undergraduate degree & 51 & 22.7 \\
\hline Postgraduate degree & 7 & 3.1 \\
\hline \multicolumn{3}{|l|}{ Nationality (valid n=222) } \\
\hline British & 57 & 25.3 \\
\hline Dutch & 33 & 14.7 \\
\hline French & 10 & 4.4 \\
\hline Belgian & 10 & 4.4 \\
\hline German & 18 & 8.0 \\
\hline Russian & 42 & 18.7 \\
\hline Lebanese & 27 & 12.0 \\
\hline Israeli & 25 & 11.1 \\
\hline \multicolumn{3}{|c|}{ Number of hotel visits (valid $n=219$ ) } \\
\hline First time & 51 & 22.7 \\
\hline Second time & 87 & 38.7 \\
\hline Third time & 52 & 23.1 \\
\hline Fourth time & 14 & 6.2 \\
\hline Fifth Time and over & 15 & 6.7 \\
\hline
\end{tabular}

Table 2. Means and standard deviations of hotel servicescape and customer satisfaction items.

\begin{tabular}{|l|c|c|}
\hline Factors and items & Mean & S.D. \\
\hline Ambient conditions & 3.19 & 1.15 \\
\hline Heating/Cooling is sufficient in public areas of the hotel. & 2.96 & 1.23 \\
\hline Background music in the hotel is pleasant. & 3.22 & 1.21 \\
\hline The hotel has a pleasant odor. & 3.24 & 1.21 \\
\hline Lighting in public areas of the hotel is sufficient. & 3.34 & 1.16 \\
\hline Spatial layout & 3.30 & 1.02 \\
\hline
\end{tabular}




\begin{tabular}{|l|c|c|}
\hline Factors and items & Mean & S.D. \\
\hline Access to elevators is easy. & 3.22 & 1.18 \\
\hline The layout of the hotel is appropriate for accessing pool areas. & 3.34 & 1.10 \\
\hline The layout of the hotel is appropriate for accessing public areas. & 3.33 & 1.10 \\
\hline Decor & 3.41 & 0.96 \\
\hline The colors of the floors and walls in the hotel are pleasant. & 3.46 & 1.08 \\
\hline Room furnishings are of high quality. & 3.38 & 1.14 \\
\hline Public area furnishings are of high quality. & 3.34 & 1.03 \\
\hline Signs and symbols & 3.37 & 0.98 \\
\hline The signs in the hotel are large enough. & 3.36 & 1.09 \\
\hline The signs in the hotel are easily understandable. & 3.35 & 1.05 \\
\hline The signs in the hotel make it easier to find where I want to go. & 3.39 & 1.14 \\
\hline Customer satisfaction & 3.45 & 0.99 \\
\hline I am satisfied with my experiences in this hotel. & 3.45 & 1.07 \\
\hline I have had pleasurable stays in this hotel. & 3.44 & 1.10 \\
\hline I am satisfied with this hotel overall. & 3.46 & 1.10 \\
\hline My experiences at this hotel have exceeded my expectations. & 3.50 & 1.14 \\
\hline
\end{tabular}

When the arithmetic averages regarding the servicescape elements in the hotels in Table 2 are examined, it is seen that the averages of all factors are slightly above 3, which is the scale average score. The highest servicescape average belongs to the decor dimension $(\bar{\square}=3.41)$. The most positive view in this dimension is that "the colors of the walls and floors are pleasant". Similarly, the participants' opinions about satisfaction were slightly higher than the average scale score of 3 .

Table 3. Confirmatory factor analysis for hotel servicescape

\begin{tabular}{|c|c|c|c|c|}
\hline Construct/item & $\begin{array}{l}\text { Standardized } \\
\text { loading }\end{array}$ & $\begin{array}{l}\text { Cronbach's } \\
\text { Alpha }\end{array}$ & CR & AVE \\
\hline Ambient conditions & & 0.94 & 0.93 & 0.77 \\
\hline Heating/Cooling is sufficient in public areas of the hotel. & 0.86 & & & \\
\hline Background music in the hotel is pleasant. & 0.86 & & & \\
\hline The hotel has a pleasant odor. & 0.92 & & & \\
\hline Lighting in public areas of the hotel is sufficient. & 0.88 & & & \\
\hline Spatial layout & & 0.88 & 0.87 & 0.69 \\
\hline Access to elevators is easy. & 0.87 & & & \\
\hline The layout of the hotel is appropriate for accessing pool areas. & 0.82 & & & \\
\hline The layout of the hotel is appropriate for accessing public areas. & 0.81 & & & \\
\hline Decor & & 0.86 & 0.86 & 0.67 \\
\hline The colors of floors and walls in the hotel are pleasant. & 0.82 & & & \\
\hline Room furnishings are of high quality. & 0.82 & & & \\
\hline Public area furnishings are of high quality. & 0.83 & & & \\
\hline Signs and symbols & & 0.87 & 0.89 & 0.73 \\
\hline The signs in the hotel are large enough. & 0.90 & & & \\
\hline
\end{tabular}




\begin{tabular}{|c|c|c|c|c|}
\hline Construct/item & $\begin{array}{l}\text { Standardized } \\
\text { loading }\end{array}$ & $\begin{array}{l}\text { Cronbach's } \\
\text { Alpha }\end{array}$ & CR & AVE \\
\hline The signs in the hotel are easily understandable. & 0.81 & & & \\
\hline The signs in the hotel make it easier to find where I want to go. & 0.85 & & & \\
\hline
\end{tabular}

The following is manifested when the goodness of fit of the model in Table 3 is examined; $\mathrm{X}^{2}=157.494, \mathrm{df}=56, \mathrm{X}^{2} / \mathrm{df}=2.81, \mathrm{p}<0.000, \mathrm{AGFI}=0.85, \mathrm{GFI}=0.90, \mathrm{CFI}=0.96, \mathrm{NFI}=0.94$. According to these values, the compliance values in the measurement model are acceptable (Engel et al., 2003).

Discriminant validity and convergent validity were used to determine the construct validity of the scale. Three methods were used to evaluate convergent validity: Factor loadings, composite reliability (CR) and average variance extracted (AVE) values (Hair et al. 2014: 618-619).

According to Hair et al. (2014: 618) factor loadings in the confirmatory factor analysis should be 0.70 and above. The confirmatory factor analysis reveals that the factor loadings of the expressions in the scale measuring the servicescape are over 0.70 . In the literature, it is emphasized that the AVE value should be 0.50 and above (Bagozzi, Yi, 1988: 82; Hair et al. 2014: 619) and CR value should be 0.70 and above (Hair et al. 2014: 619). When the data in Table 3 is examined, it is seen that the AVE values of all dimensions are above 0.50 and the CR values are above 0.70 .

In discriminant validity, the correlation coefficients between the square roots of the AVE values and the structures are compared. The correlation values between the structures should be lower than the square roots of the AVE values (Fornell, Larcker, 1981). When the data in Table 4 is examined, it is seen that the correlation coefficients between the structures are lower than the square root values of AVE. When all the findings were evaluated together, it can be said that the construct validity of the scale was achieved.

Table 4. Discriminant validity

\begin{tabular}{|l|c|c|c|c|}
\hline & Ambient Conditions & Spatial Layout & Decor & Signs and Symbols \\
\hline Ambient Conditions & 0.877 & & & \\
\hline Layout & 0.789 & 0.830 & & \\
\hline Decor & 0.713 & 0.774 & 0.818 & \\
\hline Signs and Symbols & 0.696 & 0.712 & 0.775 & 0.854 \\
\hline
\end{tabular}

Note. The diagonals (in bold) represent the square root of the AVE.

Table 5. Regression results of the influence of hotel servicescape on customer satisfaction*

\begin{tabular}{|l|c|c|c|c|c|c|c|}
\hline & B & SE B & $\begin{array}{c}\text { Standardized } \\
\text { Beta }\end{array}$ & $\mathrm{t}$ & Sig. & Tolerance & VIF \\
\hline Constant & .464 & .147 & & 3.151 & .000 & & \\
\hline Ambient Conditions & .126 & .059 & .141 & 2.132 & .034 & .335 & 2.986 \\
\hline Spatial Layout & .103 & .070 & .106 & 1.459 & .146 & .281 & 3.560 \\
\hline Decor & .200 & .073 & .195 & 2.735 & .000 & .294 & 3.400 \\
\hline Signs and Symbols & .465 & .065 & .461 & 7.113 & .000 & .351 & 2.846 \\
\hline \multicolumn{7}{|c|}{} \\
\hline
\end{tabular}

* Dependent variable: customer satisfaction 
Table 5 shows the results of the multiple linear regression analysis regarding the effect of hotel servicescape dimensions on customer satisfaction. The fact that the Durbin Watson value (2.082) in auto-correlation (Field, 2009: 220), VIF values are less than 10 and tolerance values are greater than 0.10 (Pallant, 2007: 156) in Table 6 indicate that multicollinearity is not a problem. These results indicate that the data are suitable for regression analysis.

When the data in Table 5 were examined, the multivariate linear regression model among the variables was found to be significant $(\mathrm{F}=114.557 ; \mathrm{p}<0.01)$. The calculated $\mathrm{R}_{2}=.676$ indicates that the model's disclosure ratio is $67.6 \%$ in terms of the dimensions of the hotel servicescape (ambient conditions, spatial layout, decor, signs and symbols). When the p values of the independent variables in Table 5 were examined, it was seen that while the dimensions of ambient conditions, decor, signs and symbols had a significant contribution on the dependent variable, the spatial layout dimension ( $\mathrm{p}>0.05$ ) did not have a significant contribution. According to the standardized Beta coefficients in Table 5 , signs and symbols are the most important factors affecting the satisfaction of hotel customers. Other most important factors are decor and ambient conditions, respectively.

\section{Conclusions}

In this study, which aimed to determine the effect of servicescape in hotels on customer satisfaction, it is seen that the perceptions and satisfaction levels of the hotel customers in the sample group are slightly above the average value of 3 points on the scale.

This study has manifested that servicescape in hotels has an impact on customer satisfaction. It was shown that ambient conditions, decor, signs and symbols have a significant effect on customer satisfaction. According to the results of the study, signs and symbols are the most important factors affecting customer satisfaction. The hotels examined within the scope of this study are resort hotels operating an all-inclusive system. Therefore, these hotels are spread over large areas. For this reason, customers may want to find where they want to go within the hotel without difficulty. At this point, the importance of signs and guiding signboards in hotels increases. According to Siu et al. (2012), signs and symbols are important tools in guiding customer behaviors in an enterprise and even in conveying the cultural values of businesses to customers. These elements play an important role in creating the first impression of customers regarding all aspects of servicescape in an enterprise.

Adyozi and Klutse (2015) concluded that servicescape in hotels has an impact on customer satisfaction in their study. The authors concluded that tools, equipment, odors and lighting had more impact on customer satisfaction. Faizan and Muslim (2014) found that physical evidence have an impact on customer satisfaction in their study at resort hotels in Nanjing, Hangzhou and Shanghai. Lin (2009) concluded that ambient conditions such as music and color used in hotel bars affect customer satisfaction.

In this study, it was found that the spatial layout in the hotels did not affect customer satisfaction. Some studies support this result. Ryu (2010), Han and Ryu (2009) found that spatial layout had no effect on customer satisfaction in their study involving first-class restaurants.

In conclusion, when both the results obtained from this study and other studies in the literature are taken into consideration, it is seen that servicescape in hotels has a significant effect on customer satisfaction. However, the results of this and other studies also show that some factors do not affect customer satisfaction. This may vary depending on customer profile, expectations and / or the type of enterprise. 
Although there are many different factors that affect customer satisfaction in hotel establishments (such as the quality of the rooms, the value for money, the variety of services, security), servicescape also needs to be carefully considered by managers. On the basis of this study, hotel managers should give more importance to signs and symbols that guide customers correctly within the hotel. Furthermore, elements such as the colors used in the hotel, the quality of furniture, odors, music and heating / cooling are issues which should also be taken into consideration.

\section{References}

Adzoyi, N. P., Klutse, M. C. 2015. Servicescape, customer satisfaction and loyalty in Ghanaian hotels. Journal of Tourism, Hospitality and Sports 10, 30-36.

Arnold, J. S, Handelman, J., Douglas J. T. 1996. Organizational legitimacy and retail store patronage. Journal of Business Research 35(3), 229-239.

Bagozzi, P. R., Yi, Y. 1998. On the evaluation of structural equation models. Journal of the Academy of Marketing Science 16(1), 74-94.

Baker J. 1987. The role of the environment in marketing services: The consumer perspective in czepiel, J., Congram, C.A. and Shanahan, J. (Eds), the services challenge: Integrating for competitive advantage. American Marketing Association 79-84.

Bitner, M. 1992. Servicescapes: The impact of physical surroundings on customers and employees. Journal of Marketing 56(2), 57-71.

Cheng, L. B., Gan, C. C., Imrie, C. B., Mansori, S. 2019. Service recovery, customer satisfaction and customer loyalty: evidence from Malaysia's hotel industry. International Journal of Quality and Service Sciences 11(2), 187-203.

Choi, T. Y., Chu, R. 2001. Determinants of hotel guests' satisfaction and repeat patronage in the Hong Kong hotel industry. International Journal of Hospitality Management 20(3), 277-297.

Cronin, J. J., Jr. (2003). Looking back to see forward in services marketing: Some ideas to consider. Managing Service Quality 13(5), 332-337

Dedeoğlu B. B., Küçükergin, G. K., Balıkçığlu, S. 2015. Understanding the relationships of servicescape, value, image, pleasure, and behavioral intentions among hotel customers, Journal of Travel \& Tourism Marketing 32, 42-61

Dedeoğlu, B.B., Bilgihan A., Ye B. H., Buonincontri P., Okumus F. 2018. The impact of servicescape on hedonic value and behavioral intentions: The importance of previous experience. International Journal of Hospitality Management 72, 10-20.

Del Bosque, I. A. R., Hector, S. M., Collado, J. 2006. The role of expectations in the consumer satisfaction formation process: Empirical evidence in the travel agency sector. Tourism Management 27, 410-419.

Dominici, G., Guzzo, R. 2010. Customer satisfaction in the hotel industry: a case study from Sicily. International Journal of Marketing Studies 2(2), 3-12.

Engel, K. S., Moosbrugger, H., Müler, H. 2003. Evaluating the fit of structural equation models: Tests of significance and descriptive goodness-of-fit measures. Methods of Psychological Research Online 8(2), 23-74.

Evangelista, F., Dioko, A. N. L. 2010. Interpersonal influence and destination brand equity perceptions. International Journal Of Culture, Tourism and Hospitality Research 5(3), 316328. 
Faizan, A., Muslim, A. 2014. The influence of physical environment on emotions, customer satisfaction and behavioral intentions in Chinese resort hotel industry. J. Global Business Advancement 7(3), 249-266.

Field, A. 2009. Discovering statistics using spss. London: SAGE Publications.

Fornell, C., Larcker, D. F. 1981. Evaluating Structural Equation Models with Unobservable Variables and Measurement Error. Journal of Marketing Research 18(1): 39-50.

González-Mansilla, Ó., Berenguer-Contrí, G., Serra-Cantallops, A. 2019. The impact of value co-creation on hotel brand equity and customer satisfaction. Tourism Management, 75, 51-65.

Gu, H., Ryan, C. 2008. Chinese clientele at Chinese hotels: Preferences and satisfactions. International Journal of Hospitality Management 27(3), 337-345.

Hair, J. F., Black, C. W., Babin, J. B., Anderson, R. E. 2014. Multivariate data analysis. Edinburgh Gate Harlow: Pearson Education Limited. (7th ed.)

Han, H., Ryu, K. 2009. The roles of the physical environment, price perception, and customer satisfaction in determining customer loyalty in the restaurant industry. Journal of Hospitality \& Tourism Research 33(4), 487-510.

Hee Lee, S., Lee, H. 2015. The design of servicescape based on benefit sought in hotel facilities: A survey study of hotel consumers in Seoul. Journal of Asian Architecture and Building Engineering, September 14(3), 633-640.

Heung, V. C., Gu, T. 2012. Influence of restaurant atmospherics on patron satisfaction and behavioral intentions. International Journal of Hospitality Management 31(4), 1167-1177.

Hooper, D., Coughlan, J., Mullen, M. 2013. The servicescape as an antecedent to service quality and behavioral intentions. Journal of Services Marketing 27(4), 271-280.

Hu, H.-H. S., Kandampully, J., Juwaheer, T. D. 2009. Relationships and impacts of service quality, perceived value, customer satisfaction, and image: An empirical study. The Service Industries Journal 29(2), 111-125.

Joanne Chan, H. S., Penny Wan, K. Y., Zoe Tam, T. U. 2019. Tourists' description of their experiences of the servicescape of Integrated resorts: the case of Macau. International Journal of Hospitality \& Tourism Administration, doi.org/10.1080/15256480.2019.1641453

Juhari, H. N., Ali. M. H., Khair, N. 2012. The shopping mall servicescape affects customer satisfaction. 3rd International Conference on Business and Economic Research. Bandung, Indonesia.

Kotler, P. 1973. Atmospherics as a marketing tool. Journal of Retailin, 49(4), 48-64.

Kwortnik, J. R., Han, X. 2011. The influence of guest perceptions of service fairness on lodging loyalty in China. Cornell Hospitality Quarterly 52(3), 321-332.

Lap-Kwong, D. 2017. The role of servicescape in hotel buffet restaurant. Journal of Hotel \& Business Management 6(1), 1-8.

Lin, Y. I. 2009. Management the combined effect of color and music on customer satisfaction in hotel bars. Journal of Hospitality Marketing $\mathcal{E}$ Management 19(1), 22-37.

Liu, Y., Jang, S. S. 2009. The effects of dining atmospherics: An extended Mehrabian-Russell model. International Journal of Hospitality Management 28(4), 494-503.

Mathwick, C., Malhotra, N., Rigdon, E. 2001. Experiential value: Conceptualization, measurement and application in the catalog and internet shopping. Journal of Retailing 77(1), 39-56.

Miles, P., Miles, G., Cannon, A. 2012. Linking servicescape to customer satisfaction: exploring the role of competitive strategy. International Journal of Operations E Production Management 32(7), 772-795. 
Muğla Provincial Directorate of Culture and Tourism. 2019. Tourism Statistics. Retrieved from https://mugla.ktb.gov.tr/Eklenti/61356,ozetpdf.pdf?o

Myers, N. D., Ahn, S., Jin, Y. 2011. Sample size and power estimates for a confirmatory factor analytic model in exercise and sport: A monte carlo approach. Research Quarterly for Exercise and Spor, 82(3), 412-423.

Pallant, J. 2007. SPSS. A step-guide to data analysis using SPSS version 15. New York: Open University Press. Third Edition.

$\mathrm{Qu}, \mathrm{H}$., Ryan, B., Chu, R. 200o. The importance of hotel attributes in contributing to travelers' satisfaction in the Hong Kong hotel industry. Journal of Quality Assurance in Hospitality \& Tourism 1(3), 65-83.

Radojevic, T. Stanisic, N., \& Stanic, N. 2015. Ensuring positive feedback: Factors that influence customer satisfaction in the contemporary hospitality industry. Tourism Management 51, 13-21

Reimer, A., Kuehn, R. 2005. The impact of servicescape on quality perception. European Journal of Marketing 39( 7/8), 785-808.

Republic of Turkey Ministry of Culture and Tourism. 2019. Facility (Ministry) Certified Facility Accommodation Statistics. Retrieved from https://yigm.ktb.gov.tr/TR-201121/ isletme-bakanlik-belgeli-tesis-konaklama-istatistikleri.html

Rosenbaum, S. M, Massaih, C. 2011. An expanded servicescape perspective. Journal of Service Management 22(4), 471-490.

Roy, A., Tai, S. T. C. 2003. Store environment and shopping behavior: The role of imagery elaboration and shopping orientation. Journal of International Consumer Marketing 15(3), 71-99.

Ryu, K. 2010. The influence of dining environmental perceptions on behavioral intentions through customer satisfaction in the upscale restaurant context. Annual Conference proceedings of research and academic papers. Catalina İsland, Mexico, 18-22 October, pp.185203.

Ryu, K., Han, H. 2010. Influence of the quality of food, service, and physical environment on customer satisfaction and behavioral intention in quick-casual restaurants: Moderating role of perceived price. Journal Of Hospitality \& Tourism Research 34(3), 310-329.

Shiel, G., Cartwright. F. 2015. Analyzing Data from A National Assessment of Educational Achievement. Washington DC: World Bank Group.

Siu, Yee-Man. N., Wang, K. Y. P., Dong, P. 2012. The impact of the servicescape on the desire to stay in convention and exhibition centers: The case of Macao. International Journal of Hospitality Management 31(1), 236-246

Turley, L.W., Milliman, R.E. 20oo. Atmospheric effects on shopping behavior: A review of the experimental evidence. Journal of Business Research 49(2), 193-211.

Voon, H. B. 2011. Service environment of restaurants: Findings from the youth customers. Journal of Asian Behavioural Studies 1(2), 45-56.

Weinrach, J. 200o. Environmental psychology: Why should we care?. Environmental Quality Management 10(2), 83-86.

Woo, E., Kim, H., Uysal, M. 2015. Life satisfaction and support for tourism development. Annals of Tourism Research 50, 84-97.

$\mathrm{Xu}, \mathrm{X} ., \mathrm{Li}, \mathrm{Y} .2016$. The antecedents of customer satisfaction and dissatisfaction toward various types of hotels: A text mining approach. International Journal of Hospitality Management 55, 57-69

Yen-Lun Su, A. 2004. Customer satisfaction measurement practice in Taiwan hotels. Hospitality Management 23, 397-408. 